\title{
Evaluasi Implementasi Pembelajaran Praktik Selama Pandemi Covid-19 Program Studi Pendidikan Tata Rias dan Kecantikan
}

\author{
Erin Flowriza $^{1 *}$, Rahmiati ${ }^{2}$ (iD \\ ${ }^{1,2}$ Fakultas Pariwisata dan Perhotelan, Universitas Negeri Padang, Indonesia \\ *Corresponding author: erinflowriza123@gmail.com
}

\section{Abstrak}

Penelitian ini bertujuan untu mengganalisis evaluasi implementasi pembelajaran tematik selama pandemic covid-19. Jenis penelitian yang digunakan adalah evaluasi (Evaluation Research) dengan model Context, Input, Process, Product (CIPP). Metode penelitian yang digunakan adalah metode kombinasi (Mixed Method) dengan pendekatan kuantitatif dan kualitatif secara urutan pembuktian (sequential explanatory). Pendekatan kuantitatif pada penelitian ini menggunakan pengolahan statistik dan pendekatan kualitatif. Metode pwngumpulan data menggunakan dokumentasi, wawancara, maupun observasi kepada subjek penelitian. Responden penelitian evaluasi untuk pendekatan kuantitatif adalah mahasiswa semester 5 yang sedang mengambil Mata Kuliah Wajib (Pembelajaran Praktik) Program Studi Pendidikan Tata Rias dan Kecantikan yang telah menerapkan pembelajaran praktik dimasa pandemi Covid-19 selama satu semester. Responden untuk penelitian kualitatif adalah staf pengajar Mata Kuliah Wajib Program Studi Pendidikan Tata Rias dan Kecantikan telah menerapkan pembelajaran praktik dimasa pandemi Covid-19 selama satu semester. Hasil penelitian menunjukkan untuk indikator hasil (product) implementasi pembelajaran praktek dimasa pandemi covid-19 program studi pendidikan tata rias dan kecantikan diperoleh sebesar 3,91 dengan tingkat pencapaian 78,22\%. Dapat disimpulkan implementasi pembelajaran praktik selama pandemic covid-19 sudah berjalan dengan cukup baik. Namun pelaksanaan pembelajaran praktik masih menimbulkan beberapa kendala. Adanya evaluasi implementasi pembelajaran praktik dapat meningkatkan proses pembelajaran menjadi optimal.

Kata kunci: Evaluasi, Pembelajaran Praktik, Pandemi Covid-19

\section{Abstract}

This study aims to analyze the evaluation of the implementation of thematic learning during the covid-19 pandemic. The type of research used is evaluation (Evaluation Research) with the Context, Input, Process, Product (CIPP) model. The research method used is a combination method (Mixed Method) with quantitative and qualitative approaches in a sequential explanatory manner. The quantitative approach in this study uses statistical processing and a qualitative approach. The data collection method uses documentation, interviews, and observations to research subjects. Respondents for evaluation research for the quantitative approach are 5th semester students who are taking Compulsory Courses (Practice Learning) for the Makeup and Beauty Education Study Program who have implemented practical learning during the Covid-19 pandemic for one semester. The respondents for the qualitative research were the teaching staff of the Compulsory Course for the Makeup and Beauty Education Study Program who had implemented practical learning during the Covid-19 pandemic for one semester. The results showed that the product indicators for the implementation of practical learning during the COVID-19 pandemic, the cosmetology and beauty education study program was 3.91 with an achievement rate of $78.22 \%$. It can be concluded that the implementation of practical learning during the COVID-19 pandemic has gone quite well. However, the implementation of practical learning still poses several obstacles. The existence of an evaluation of the implementation of practical learning can improve the learning process to be optimal.

Keywords: Evaluation, Practical Learning, Covid-19 pandemic

\begin{tabular}{|c|c|c|}
\hline \multicolumn{2}{|l|}{ History: } & Publisher: Undiksha Press \\
\hline Received & : 15 Mei 2021 & Licensed: This work is licensed under \\
\hline Revised & : 25 Mei 2021 & a Creative Commons Attribution 4.0 License \\
\hline Accepted & : 10 Juni 2021 & (1) (0) \\
\hline Published & : 25 Juli 2021 & C) $E Y$ SA \\
\hline
\end{tabular}

\section{Pendahuluan}

Pendidikan merupakan salah satu kunci terbentuknya sumber daya manusia yang kompeten dalam membangun bangsa. Pendidikan di perguruan tinggi selain menuntut kemampuan akademik (hard skill), mahasiswa juga dituntut untuk dapat meningkatkan kemampuan personal (soft skills) sehingga mahasiswa siap memasuki dunia kerja yang sesungguhnya setelah menyelesaikan studi. Tanpa melalui proses pendidikan yang baik akan 
sulit bagi seseorang untuk menyesuaikan diri dengan perkembangan dan kemajuan zaman. Oleh karena itu pendidikan mampu menjawab tantangan kehidupan zaman modern yang sangat diperlukan. Pendidikan bidang keahlian, seperti pendidikan tata rias dan kecantikan hendaknya selain memberikan teori-teori yang cukup, juga perlu memberikan praktik. Kenyataannya pandemi Covid-19 memberikan dampak pada pendidikan (Setiawan, 2020; Siahaan, 2020). Beberapa universitas menerapkan kebijakan kegiatan belajar mengajar dari jarak jauh atau kuliah online (Dewi, 2020; Robandi \& Mudjiran, 2020). Terhitung sejak tanggal 16 Maret 2020 pelaksanaan perkuliahan di UNP dilaksanakan secara daring/online. Perkuliahan dilaksanakan dengan menggunakan flatform online lainnya sampai dengan akhir semester. Adapun flatform online yang di gunakan yaitu WhatApps, e-mail, Youtube dan Zoom Cloud Meeting (Mansyur, 2020; Syarifudin, 2020). Universitas Negeri Padang sebagai salah satu Perguruan Tinggi Negeri yang memiliki fokus secara konsisten pada pendidikan serta mampu melahirkan lapangan profesional lainnya. Adapun program studi Pendidikan yang ada pada Universitas Negeri Padang salah satunya adalah Pendidikan Tata Rias dan Kecantikan yang merupakan suatu program kependidikan yang memiliki tujuan menghasilkan Sarjana Pendidikan profesional dalam bidang kecantikan.

Berdasarkan hasil wawacara banyaknya mahasiswa yang kurang mengerti dalam melakukan perkuliahan online dimasa pandemi ini. Dimasa pandemi Covid-19 proses pembelajaran yang dilaksanakan secara daring dapat terlaksana pada mata kuliah Pembelajaran praktik pada BP 2018 semester 5 tahun ajaran Juli-Desember 2020 yang akan diteliti adalah Tata Rias Panggung, Tata Rias Pengantin Indonesia, Smoothing dan Rebonding. Peneliti memilih mata kuliah tersebut karena Namun pelaksanaan pembelajaran daring tersebut memiliki dampak yaitu ancaman putus sekolah, penurunan pencapaian belajar atau materi yang di dapat peserta didik, peningkatan stres oleh peserta didik dan pandemi covid 19 menyebabkan pembelajaran praktik tidak dapat diterapkan dengan optimal. Tujuan pembelajaran praktik adalah meningkatkan kemampuan praktik mahasiswa terhadap kondisi nyata di lapangan, menambah wawasan tentang informasi serta melatih pola pikir mahasiswa untuk dapat menggali permasalahan, kemudian akan dianalisa dan dicari penyelesaiannya, memperluas wawasan umum mahasiswa tentang orientasi pengembangan teknologi di masa yang akan datang, sesuai teori yang diberikan di kelas dengan tugas yang dihadapi di lapangan, memberikan solusi terhadap masalah yang ada saat praktek (Sutrisno \& Siswanto, 2016). Permasalahan tersebut perlu diselesaikan dengan berbagai solusi.

Salah satu solusi yang dapat dilakukan yaitu dengan mengevaluasi implementasi pembelajaran praktik selama pandemi covid-19 program studi pendidikan tata rias dan kecantikan. Evaluasi merupakan upaya pengendalian mutu pembelajaran yang mendorong akuntabilitas mutu proses pendidikan (Mansyur, 2020; Sudijono, 2005). Evaluasi yang sering dipahami selama ini dalam dunia pendidikan adalah terbatas pada penilaian saja. Penilaian ini dilakukan secara formatif dan sumatif. Ketika sudah dilakukan penilaian, dianggap sudah melakukan evaluasi. Pemahaman demikian tidaklah terlalu tepat. Pelaksanaan penilaian cenderung hanya melihat capaian tujuan pembelajaran saja. Pada hal, dalam proses pendidikan tersebut bukan hanya nilai yang dilihat, tetapi ada banyak faktor yang membuat berhasil atau tidaknya sebuah program. Penilaian hanya bagian kecil dari evaluasi. Evaluasi juga harus dipahami sebagai bagian dari supervisi. Evaluasi tidak hanya berurusan pada nilai yang diukur berdasarkan penyelesaian soal-soal, tetapi evaluasi program pendidikan akan mengkaji banyak faktor. Dengan demikian evaluasi program perlu diperkenalkan kepada seluruh pendidik, karena evaluasi sangat penting dalam pengembangan mutu pendidikan (Munthe, 2015).

Temuan penelitian sebelumnya menyatakan pembelajaran praktik selama pandemic mahasiswa kesulitan menentukan mengaplikasikan bahan dan kosmetika pada Rias Wajah Karakter, serta kesesuaian disain Rias Wajah (Mentari \& Rosalina, 2018). Universitas Negeri 
Padang sebagai salah satu Perguruan Tinggi Negeri yang memiliki fokus secara konsisten pada pendidikan serta mampu melahirkan lapangan profesional lainnya. Adapun program studi Pendidikan yang ada pada Universitas Negeri Padang salah satunya adalah Pendidikan Tata Rias dan Kecantikan yang mengimplementasikan pembelajaran praktik. Tujuan penelitian ini untuk mengganalisis evaluasi implementasi pembelajaran praktik selama pandemi covid-19 program studi pendidikan tata rias dan kecantikan. Adanya evaluasi ini dapat meningkatkan pembelajaran praktik selama pandemic Covid-19.

\section{Metode}

Jenis penelitian yang digunakan adalah evaluasi (Evaluation Research) dengan model Context, Input, Process, Product (CIPP) yang bertujuan untuk mengetahui akhir dari sebuah program dalam rangka menentukan rekomendasi atas kebijkan yang telah lalu dan seterusnya dengan tujuan perbaikan (Suharsono \& Sari, 2019). Metode penelitian yang digunakan adalah metode kombinasi (Mixed Method) dengan pendekatan kuantitatif dan kualitatif secara urutan pembuktian (sequential explanatory). Pendekatan kuantitatif pada penelitian ini menggunakan angka pengolahan statistik dan pendekatan kualitatif untuk mengungkap fenomena yang terjadi dan di angkat dari fakta-fakta secara wajar, bukan dari kondisi yang terkendali atau manipulasi. Dalam menguatkan deskripsi data kuantitatif digunakan data kualitatif yang di dapatkan dari hasil dokumentasi, wawancara, maupun observasi kepada subjek penelitian. Responden penelitian evaluasi untuk pendekatan kuantitatif adalah mahasiswa semester 5 yang sedang mengambil Mata Kuliah Wajib (Pembelajaran Praktik) Program Studi Pendidikan Tata Rias dan Kecantikan UNP yang telah menerapkan pembelajaran praktik dimasa pandemi Covid-19 selama satu semester. Responden untuk penelitian kualitatif adalah staf pengajar Mata Kuliah Wajib Program Studi Pendidikan Tata Rias dan Kecantikan UNP telah menerapkan pembelajaran praktik dimasa pandemi Covid-19 selama satu semester.

\section{Hasil dan Pembahasan}

Implementasi pembelajaran praktik selama pandemi covid-19 program studi pendidikan tata rias dan kecantikan terbagi dalam dua indikator/sub indikator yang ditinjau dari dampak dan pengaruh. Berdasarkan angket yang diberikan kepada 104 orang peserta didik dengan 27 butir pertanyaan, diperoleh hasil untuk indikator dampak 3,91 dengan tingkat pencapaian sebesar 78,27\% dan termasuk kedalam kategori cukup. Artinya hasil pelaksanaan implementasi pembelajaran praktik selama pandemi covid-19 program studi pendidikan tata rias dan kecantikan sudah tergolong cukup baik. Hasil wawancara mengenai dampak dapat disimpulkan bahwa dalam implementasi pembelajaran praktek dimasa pandemi covid-19 program studi pendidikan tata rias dan kecantikan adalah ketidakpuasan sebagai seorang dosen karena tidak bisa mengamati secara langsng dan memperbaiki secara langsung kesalahan-kesalahan yang terjadi saat melakukan praktek.

Hasil untuk indikator pengaruh diperoleh rata-rata sebesar 3,91 dengan tingkat presentasi sebesar 78,17\% dan termasuk kategori cukup. Artinya implementasi pembelajaran praktek dimasa pandemi covid-19 program studi pendidikan tata rias dan kecantikan memiliki pengaruh yang kurang baik bagi pembelajaran dimasa pandemi covid-19. Hasil wawancara mengenai pengaruh dapat disimpulkan bahwa implementasi pembelajaran praktek dimasa pandemi covid-19 program studi pendidikan tata rias dan kecantikan banyak mahasiswi yang kurang memahami materi praktek sehingga banyak mahasiswi yang memiliki nilai yang kurang bagus. Skor perolehan rata-rata dari indikator hasil (product) implementasi pembelajaran praktek dimasa pandemi covid-19 program studi pendidikan tata rias dan kecantikan diperoleh sebesar 3,91 dengan tingkat pencapaian 78,22\% dan termasuk 
kedalam kategori cukup. Dapat disimpulkan bahwa komponen hasil sudah memenuhi implementasi pembelajaran praktek dimasa pandemi covid-19 program studi pendidikan tata rias dan kecantikan akan tetapi masih ada beberapa indikator yang perlu dioptimalkan agar mendapatkan hasil yang cukup baik.Berdasarkan hasil penelitian implementasi pembelajaran praktik selama pandemic covid-19 sudah berjalan dengan cukup baik. Namun pelaksanaan pembelajaran praktik masih menimbulkan beberapa kendala. Pertama sarana prasarana pendukung praktik, secara keseluruhan sarana dan prasarana yang digunakan dalam pembelajaran praktik tata rias dan kecantikan dapat dikatakan sudah baik, lengkap dan terawat. Untuk peralatan yang digunakan mahasiswa merupakan milik sendiri. Untuk kualitas sarana dan prasarana yang ada sudah mencukupi untuk melaksanakan pembelajaran praktik. Selain itu sarana dan prasarana yang ada sudah cukup sesuai dengan standar sarana dan prasarana dalam standar nasional pendidikan. Karena, sarana dan prasarana yang ada dilihat dari kondisi, kualitas dan kuantitas sarana dan prasarana sudah dapat mendukung terselenggaranya proses pembelajaran baik teori maupun praktik (Pakpahan \& Fitriani, 2020).

Aktivitas peserta dalam mengikuti proses pembelajaran dan interaksi antar peserta dengan narasumber belum baik. Hal ini disebabkan mahasiswa melaksakan pembelajaran praktik secara daring sehingga interaksi mahasiswa dengan dosen maupun dengan sesama mahasiswa kurang dilaksanakan. Partisipasi peserta adalah keikutsertaan peserta dalam mengikuti proses pembelajaran yang diselenggarakan (Asmuni, 2020). Berdasarkan hasil penelitian yang dilakukan di lapangan, bahwa partisipasi peserta dalam mengikuti pembelajaran sudah baik. Tujuan dari pembelajaran praktik tata rias pengantin sudah tercapai. Namun masih mengalami kendala seperti praktik tata rias tidak maksimal karena mahasiswa melaksanakan praktik masing-masing. Selain itu dosen juga mengalami kesulitan dalam memberikan contoh langsung mengimplemantasi praktik tata rias.

Komponen konteks yang tergolong cukup perlu ditingkatkan dan komponen konteks yang cukup perlu diperbaiki lagi dalam implementasinya pada pembelajaran praktik selama pandemi covid-19 program studi pendidikan tata rias dan kecantikan. Komponen masukan ini secara keseluruhan terkategori cukup namun perlu dilakukan peningkatan agar hasil yang diperoleh bisa menjadi baik dimana hasil analisis data kuantitatif ini memiliki kesesuaian dengan data kualitatif yang menyebutkan masukan implementasi pembelajaran praktik selama pandemi covid-19 program studi pendidikan tata rias dan kecantikan ditinjau dari segi pendidik, peserta didik, sarana dan prasarana serta pembiayaan dalam pelaksanaan praktek. Komponen proses implementasi pembelajaran praktik selama pandemi covid-19 pada program studi pendidikan tata rias dan kecantikan tergolong kategori cukup baik dikarenakan masih ada sedikit masalah yang dihadapi oleh siswa serta guru yang belum terselesaikan secara maksimal. Hal ini membuktikan bahwa komponen proses ini perlu ditingkatkan untuk masa yang akan datang agar implementasi pembelajaran praktik selama pandemi covid-19 pada program studi pendidikan tata rias dan kecantikan memiliki hasil yang sangat baik, dimana hasil ini sejalan dengan analisis data kualitatif bahwa pelaksanaan proses belajar mengajar sudah baik dan kurikulum yang dijalankan sesuai dengan tuntutan pemerintah. Akan tetapi masih memiliki hambatan dalam implementasinya yaitu dalam menanggulangi kejenuhan siswa dalam melakukan praktek dirumah. Proses implementasi pembelajaran praktik selama pandemi covid-19 pada program studi pendidikan tata rias dan kecantikan ditinjau dari hasil tergolong baik dengan dimana peserta didik atau siswa memiliki pengetahuan dan keterampilan yang kurang memuaskan dibidangnya.

\section{Simpulan}

Berdasarkan hasil penelitian dapat disimpulkan bahwa implementasi pembelajaran praktik selama pandemi covid-19 program studi pendidikan tata rias dan kecantikan sudah 
berjalan cukup baik, namun masih mengalami beberapa kendala hal ini disebabkan karena adanya pandemic Covid-19. Pembelajaran praktik dapat menggunakan berbagai media pembelajaran sebagai penunjang membantu pembelajaran. sehingga dapat meningkatakan hasil pembelajaran praktik menjadi optimal.

\section{Daftar Rujukan}

Asmuni, A. (2020). Problematika Pembelajaran Daring di Masa Pandemi Covid-19 dan $\begin{array}{llll}\text { Solusi Pemecahannya. Jurnal Paedagogy, } 281 . & \text { 7(4), }\end{array}$ https://doi.org/10.33394/jp.v7i4.2941.

Dewi, W. A. F. (2020). Dampak COVID-19 Terhadap Implementasi Pembelajaran Daring Di Sekolah Dasar. Jurnal Ilmu Pendidikan, 2(1), 55-61. https://doi.org/https://edukatif.org/index.php/edukatif/index.

Mansyur, A. R. (2020). Dampak COVID-19 Terhadap Dinamika Pembelajaran Di Indonesia. Education and Learning Journal, 1(2), 113. https://doi.org/10.33096/eljour.v1i2.55.

Mentari, T. A. S., \& Rosalina, L. (2018). Penggunaan Media Pembelajaran Multimedia Interaktif Untuk Meningkatkan Aktivitas Dan Hasil Belajar Mahasiswa Pada Mata Kuliah Rias Wajah Karakter Foto/TV/Film Program Studi Pendidikan Tata Rias dan Kecantikan Jurusan Tata Rias Dan Kecantikan FPP UNP. Journal of Education Scienties, 2(2), 194-199. http://lppm.ojs.unespadang.ac.id/index.php/UJES.

Munthe, A. P. (2015). Pentingnya Evaluasi Program di Institusi Pendidikan: Sebuah Pengantar, Pengertian, Tujuan dan Manfaat. Scholaria: Jurnal Pendidikan Dan Kebudayaan, 5(2), 1-14. https://doi.org/10.24246/j.scholaria.2015.v5.i2.p1-14.

Pakpahan, R., \& Fitriani, Y. (2020). Analisa Pemafaatan Teknologi Informasi Dalam Pemeblajaran Jarak Jauh Di Tengah Pandemi Virus Corona Covid-19. JISAMAR (Journal of Information System, Applied, Management, Accounting and Researh), 4(2), 30-36. http://journal.stmikjayakarta.ac.id/index.php/jisamar/article/view/181.

Robandi, D., \& Mudjiran, M. (2020). Dampak Pembelajaran Dari Masa Pandemi Covid-19 terhadap Motivasi Belajar Siswa SMP di Kota Bukittinggi. Jurnal Pendidikan Tambusai, 4(3), 3498-3502. https://doi.org/10.31004/jptam.v4i3.878.

Setiawan, W. \& D. Y. (2020). Dampak Pandemi COVID-19 Terhadap Kegiatan Pembelajaran Online di STMIK Komputama Majenang. Teknologi Dan Bisnis, 2(2), 16-25. https://doi.org/10.37087/jtb.v2i2.21.

Siahaan, M. (2020). Dampak Pandemi Covid-19 Terhadap Dunia Pendidikan. Jurnal Kajian $\operatorname{Ilmiah}(J K I), 20(1), 1-3$.

Sudijono, A. (2005). Pengantar Evaluasi Pendidikan. Raja Grafindo.

Suharsono, R. S., \& Sari, R. P. (2019). Pengaruh Promosi Media Online terhadap Keputusan Pembelian Produk Hijab. JAMIN : Jurnal Aplikasi Manajemen Dan Inovasi Bisnis, 1(2), 41. https://doi.org/10.47201/jamin.v1i2.28.

Sutrisno, V. L. P., \& Siswanto, B. T. (2016). Faktor-Faktor Yang Mempengaruhi Hasil Belajar Siswa Pada Pembelajaran Praktik Kelistrikan Otomotif Smk Di Kota $\begin{array}{llll}\text { Yogyakarta. Jurnal } & \text { Pendidikan }\end{array}$ https://doi.org/10.21831/jpv.v6i1.8118.

Syarifudin. (2020). Implementasi Pembelajaran Daring untuk Meningkatkan Mutu Pendidikan Sebagai Dampak Diterapkan Social Distancing. 5(1), 31-34. https://doi.org/10.21107/metalingua.v5i1.7072. 